\title{
Numerical and experimental study of a waffle slab designed to serve as a tennis court floor
}

\section{Análise numérico-experimental de uma laje nervurada projetada como piso de uma quadra de tênis}
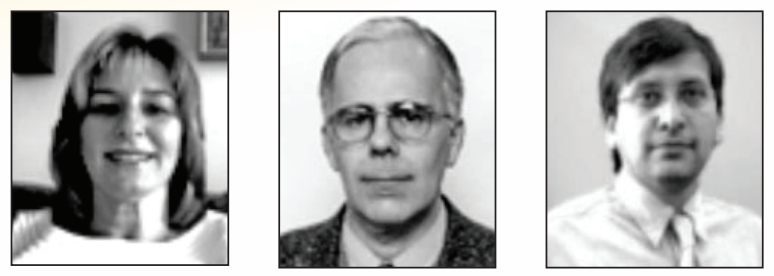

P. F. SCHWETZ a paulete.schwetz@ufrgs.br

F. P. S. L. GASTAL b francisco.gastal@gmail.com

L. C. P. SILVA $F^{\circ} \mathrm{c}$ Icarlos66@gmail.com

\begin{abstract}
Reinforced concrete waffle slabs have become a common option for designers due to a need of rationalization in construction with reduction in costs and deadlines. To better understand the behavior of this structural system, and more realistically quantify stresses and displacements, a full scale waffle slab was tested. The structure, designed to serve as a tennis court floor, was submitted to a load of $12 \mathrm{kN} / \mathrm{m}^{2}$ and instrumented to measure strains and deflections at different locations. The loading process used the floor's constructive base filling material and readings were taken at different loading stages and arrangements during the floor's construction. Test data was compared to results obtained from the matrix analysis program Sistema Computacional TQS v11.0 and from the finite element model program SAP2000 v14.2.2. Slab behavior was as expected, with deflection and bending moments close to those determined by the numerical analysis.
\end{abstract}

Keywords: waffle slab, reinforced concrete, matrix analysis of grids, finite element method.

\section{Resumo}

A necessidade de racionalização na construção civil com a minimização de custos e prazos vem fazendo das lajes nervuradas de concreto armado uma opção cada vez mais adotada pelos projetistas. Com o objetivo de compreender melhor o comportamento desse sistema estrutural e quantificar as tensões e deslocamentos da estrutura de uma forma mais realista, foi realizado um programa experimental em uma laje nervurada em escala natural. O estudo mediu deformações no concreto e deslocamentos verticais em diversos pontos da estrutura, submetida a um carregamento de $12 \mathrm{kN} / \mathrm{m}^{2}$, correspondente a várias camadas de enchimento necessárias para servir de base para quadras de tênis. Devido à impossibilidade de aplicação do carregamento experimental de forma regular e em etapas, optou-se pela realização de leituras em diferentes situações de carga. Os dados coletados experimentalmente foram comparados com os resultados de duas análises computacionais, empregando-se um modelo de análise matricial de grelhas do programa Sistema Computacional TQS v11.0 e um modelo em elementos finitos do programa SAP2000 v14.2.2. O comportamento da laje esteve dentro do previsto, com deslocamentos verticais e momentos fletores próximos aos determinados pelas análises numéricas.

Palavras-chave: laje nervurada, concreto armado, análise matricial de grelhas, elementos finitos.

\footnotetext{
Programa de Pós Graduação em Engenharia Civil, Universidade Federal do Rio Grande do Sul, paulete.schwetz@ufrgs.br, Av. Osvaldo Aranha, 99 Térreo, CEP 90035-190, Porto Alegre, Brasil;

b Programa de Pós Graduação em Engenharia Civil, Universidade Federal do Rio Grande do Sul, francisco.gastal@gmail.com, Av. Osvaldo Aranha, 99 - Térreo, CEP 90035-190, Porto Alegre, Brasil.

Programa de Pós Graduação em Engenharia Civil, Universidade Federal do Rio Grande do Sul, Icarlos66@gmail.com, Av. Osvaldo Aranha, 99 -

Térreo, CEP 90035-190, Porto Alegre, Brasil.
} 


\section{Introduction}

Sophisticated and rational structural solutions are on increasing demand in the daily work of structure designers due to the evolution of architectural designs and new construction management concepts. Therefore, it is necessary to evaluate a variety of structural systems, seeking to find the solution that can best deliver economic viability, speed and versatility of application.

According to Dias R.[1], in multi-storied reinforced concrete structures, the slabs are responsible for a significant share of the concrete consumption. In the case of solid slabs, this share reaches almost two thirds of the total volume of the structure. Therefore, it is important to study different types of slab to be used in multi-story buildings to find solutions that are both technically viable and less expensive.

From this perspective, the use of waffle slabs is proving to be an interesting option. This structural system can be defined as a set of ribs distributed in two directions, spaced at regular intervals and connected by a top concrete slab.

The waffle slab structure was conceived with the reduction of concrete below the neutral axis, creating voids in a rhythmic pattern. This leads to a reduction in the weight of the structure and to a more efficient use of materials.

However, the behavior of reinforced concrete waffle slabs still raises some questions due to their complexity, which has led some researchers to undertake numerical and experimental studies (Ajdukiewicz \& Kliszczewicz, 1986 [2]; Selistre, 2000 [3]; Abdul-Wahab \& Khalil, 2000 [4]; Dias, 2003 [1]; Soares, 2003 [5]; Schwetz, 2005 [6]; Schwetz, 2011 [7]).

In Brazil, there has been a gradual increase in the use of waffle slabs, but conventional structural arrangements made of solid slabs and concrete frames remain the preferred model for reinforced concrete structures. However, it is necessary to develop procedures and standards to guide the use of waffle slabs constructive system. In fact, as the development of numerical algorithms that allow the design of this type of structure is quite recent,

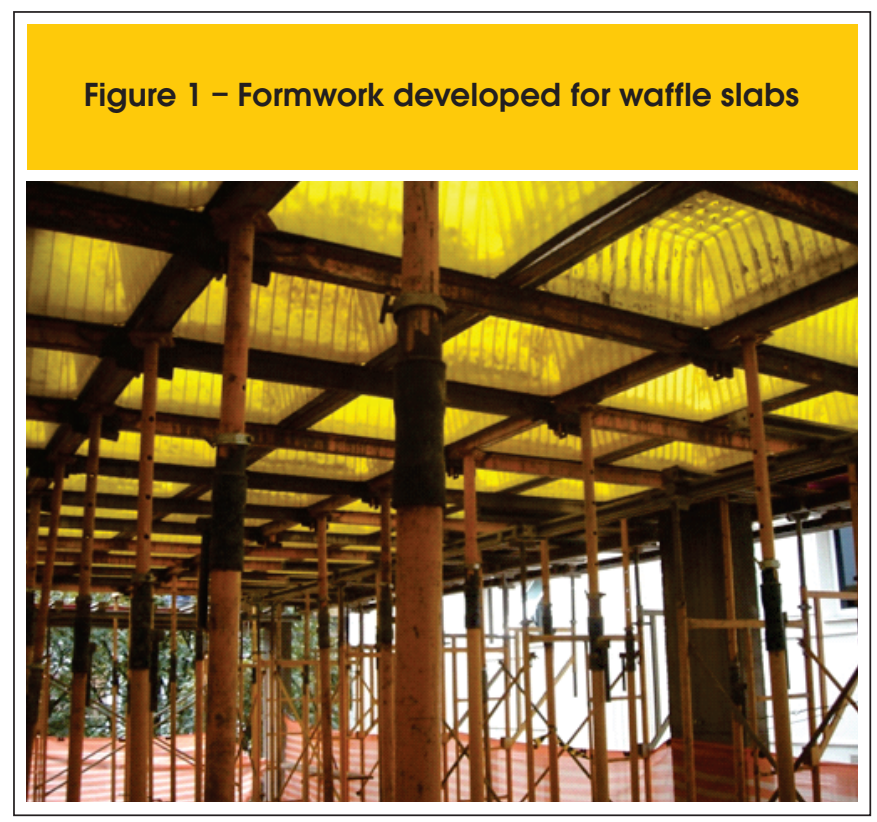

\section{Figure 2 - Position of top and bottom reinforcement}

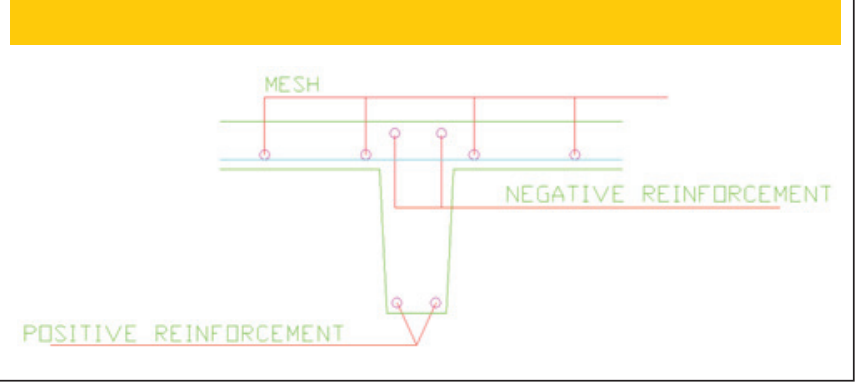

many questions still remain with regards to the quantification of the slab stresses and their adequate modeling by the design methods and the mathematical models currently used.

This study, which is part of an ongoing research project [7], seeks to improve the knowledge about reinforced concrete waffle slabs

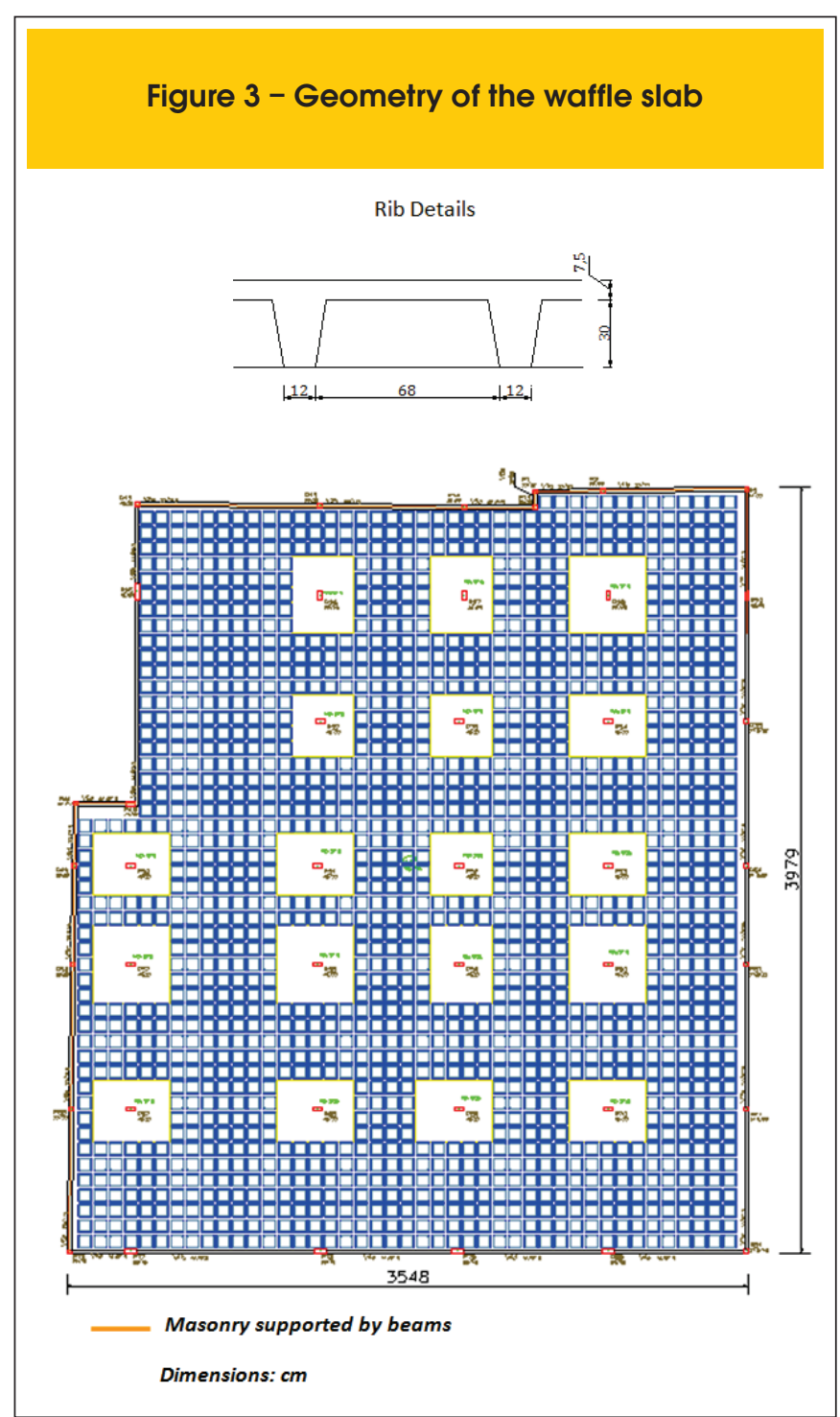


and to verify whether their behavior is adequately simulated by the design methods and mathematical models widely used today. In order to achieve this aim, an experimental program was implemented, measuring strains and deflections in a full-scale waffle slab, designed to receive several layers of filling material necessary for use as the floor of a tennis court. The experimental results were compared with results obtained from numerical analyses performed using two different approaches to represent the structure (a grid matrix analysis and FEM analysis).

\section{Experimental program}

The floor analyzed was designed commercially by a structural engineering design office located in the city of Porto Alegre, Brazil. It is to be used as a tennis court floor.

The formwork was built with plastic formwork developed for waffle slabs by Ulma Fôrmas e Escoramentos Ltda. This system is composed by a two-way ribbed structure that serves as support for the plastic molds. The ribbed structure is supported by a set of tubular metallic braces that are easy to disassemble (Fig. 1).

The slab reinforcement was made with type CA-50. The weight of positive reinforcement used was about $16,000 \mathrm{~kg}$ and the amount of negative one was around $23,000 \mathrm{~kg}$.

Fig. 2 shows the generic position of the steel in the ribs. Besides the top and bottom reinforcements predicted in the numerical analysis, the structural designer considered the possibility of tensile stress on the bottom of the slab topping located between the ribs and placed a welded CA-60 steel mesh on the bottom part of the top slab.

\subsection{Geometry and loading}

The geometry of the waffle slab floor is shown in Fig. 3. The designer used semi-inverted edge beams to increase stiffness in order to prevent excessive deformation. Around the internal columns, a $37.5 \mathrm{~cm}$ solid slab was used due to punching shear and high bending moments.
The loading adopted in the original design was the structure's own weight of $4.8 \mathrm{kN} / \mathrm{m}^{2}$ with an additional dead load of $12 \mathrm{kN} / \mathrm{m}^{2}$, a live load of $3.0 \mathrm{kN} / \mathrm{m}^{2}$ and a masonry load applied directly on the edge beams. The high value of the additional dead load is due to the several layers of the base filling material of the tennis court. Only the additional dead load was used in the experimental program.

\subsection{Instrumentation}

The experimental program predicted measurement of strains and vertical displacements.

In the concrete, strain gauges were placed in four slab locations, at the top and bottom surfaces (Fig. 4a). In the reinforcement, two strain gauges were placed at each instrumented location, protected with an epoxy based resin (Fig. 4b).

A precision optical level was used to measure the vertical displacements (Fig. 5) at locations as shown in Fig. 6.

\subsection{Testing}

The test began 63 days after casting. The loading was to be carried out in three stages and strain and vertical displacements were to be measured at the end of each loading stage. However, the load was distributed unevenly throughout the testing period. Some areas of the slab were used to store other types of material generating a non-uniform load (Fig. $7 a$ and b). Hence, readings were made at different points in time and care was taken to register the actual load applied at each reading. The process of loading the structure lasted 87 days and readings were taken at 5 different times. Cylinder tests were also carried out to determine the modulus of longitudinal elasticity of the concrete $(E)$ and the characteristic concrete strength $\left(f_{c k}\right)$. The average value of the modulus of elasticity of the concrete $\mathrm{E}_{28}$ measured experimentally was equal to $28,45 \mathrm{GPa}$, and the average concrete strength obtained at 28 days was equal to $33,27 \mathrm{MPa}$, corresponding to a concrete characteristic strength $f_{c k \text {, estimated }}$ equal to $30 \mathrm{MPa}$.

\section{Figure 4 - Position of strain gauges: (a) concrete and (b) reinforcement}

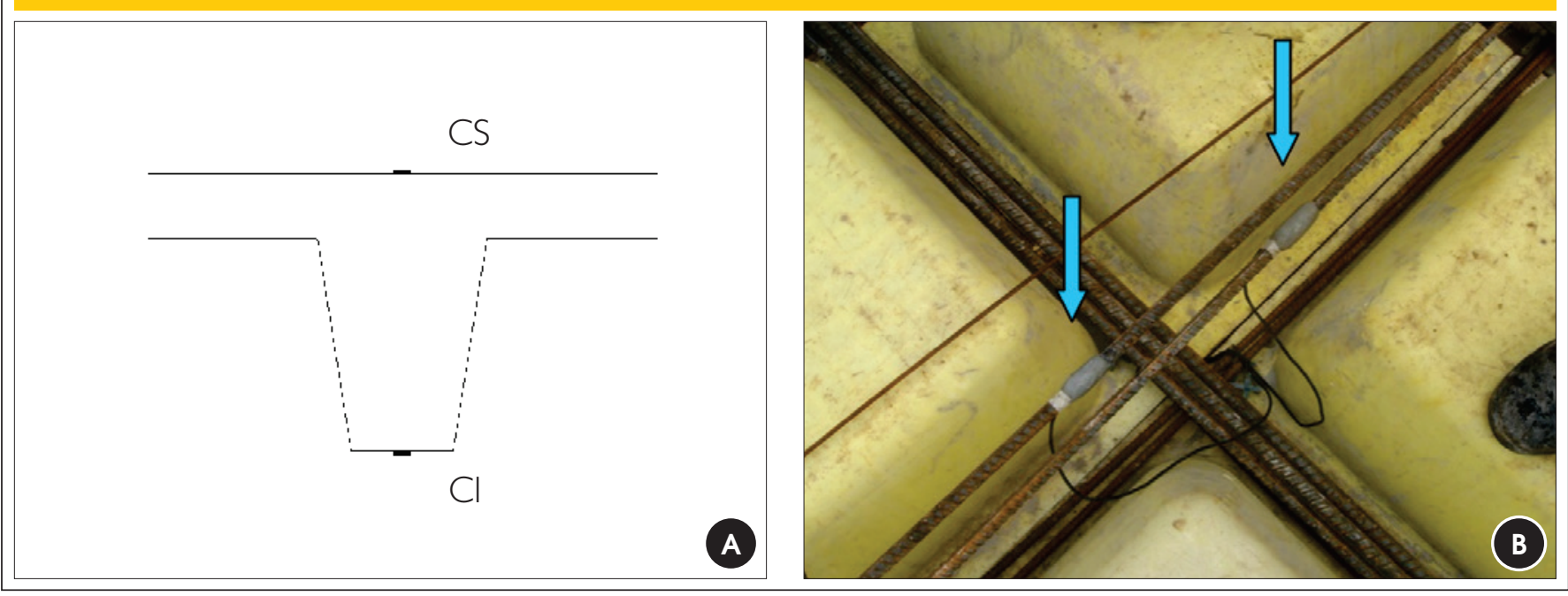




\section{Figure 5 - Vertical displacements measurement}

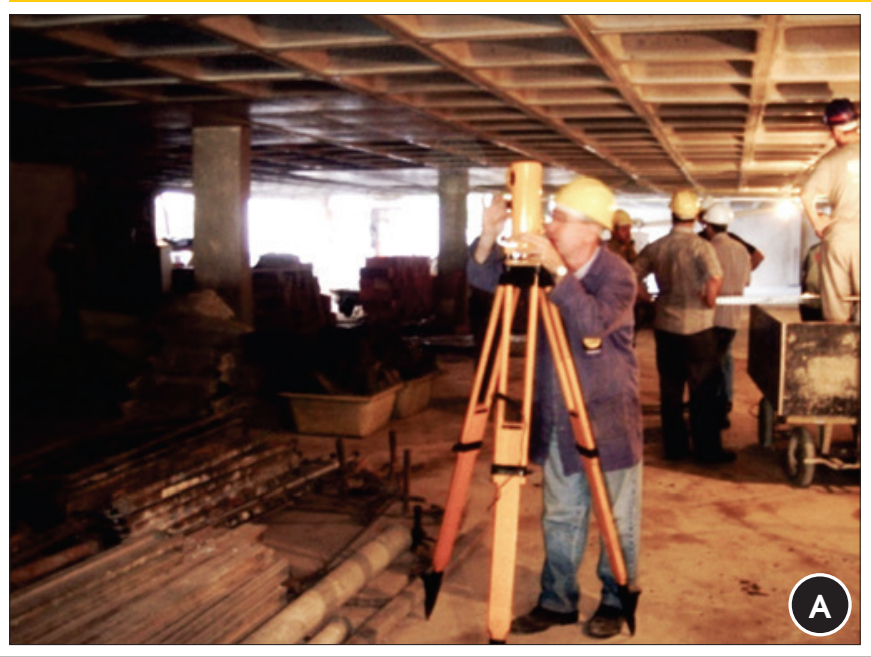

Figure 6 - Location of instrumentation

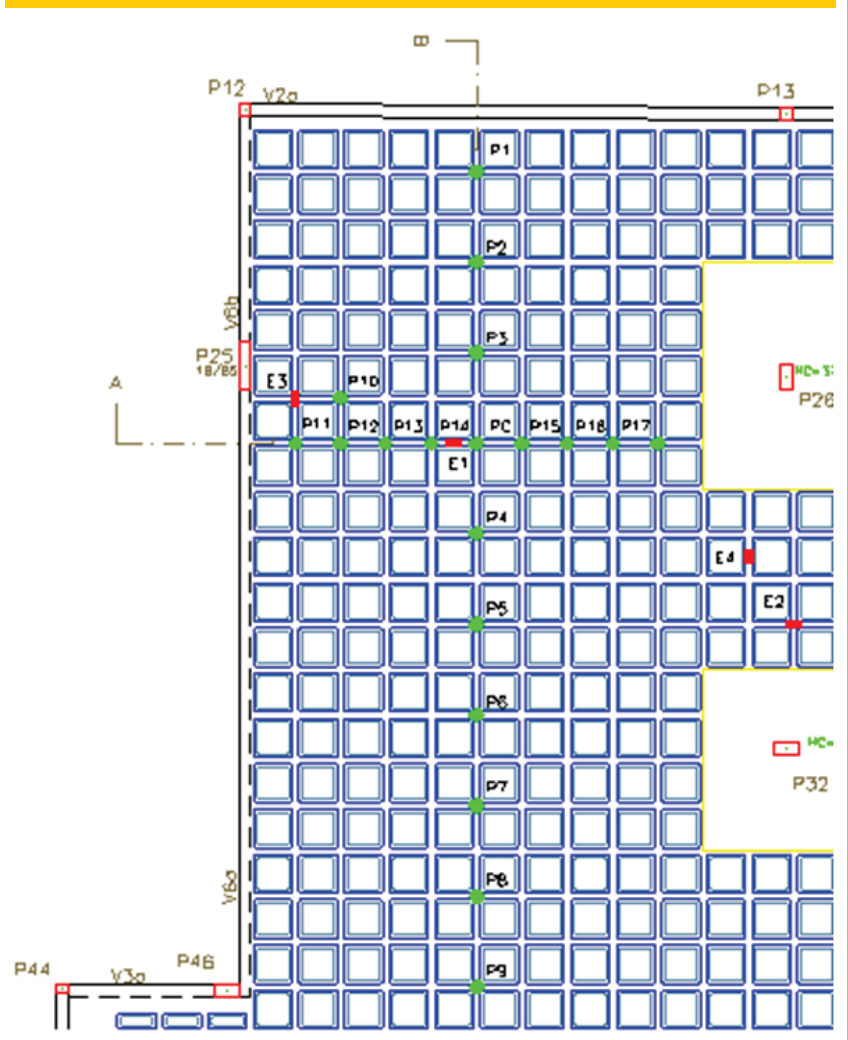

Legend

Strain Gauges

Displacement

Control Points

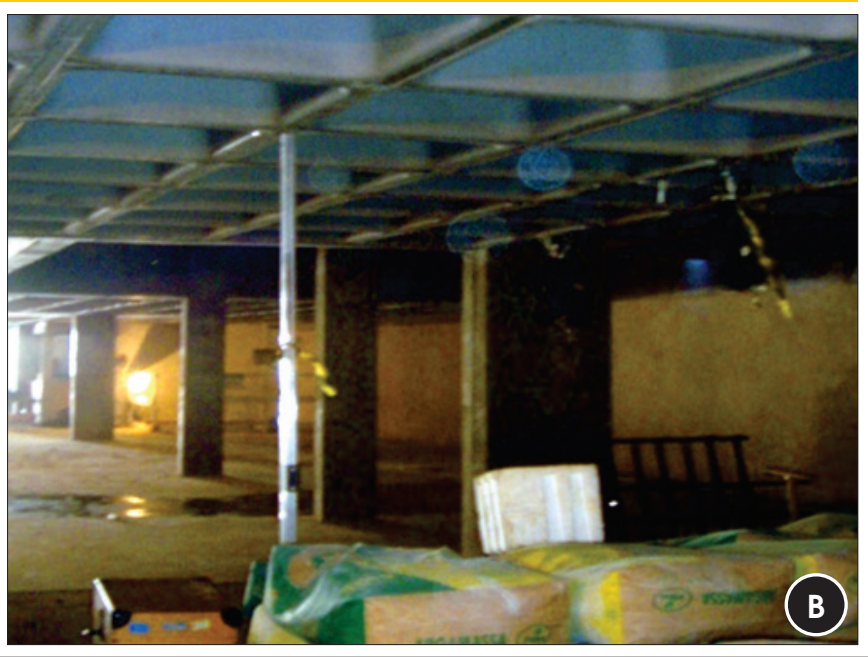

\section{Numerical analysis}

The numerical analysis was done with two computer programs traditionally used in the design and analysis of reinforced concrete waffle slabs. The results were compared to the experimental data obtained by Schwetz [7] in the actual structure, with the aim of verifying how close the mathematical models are to the actual behavior of the slab. The tested slab was numerically analyzed considering the values obtained experimentally from the test specimens for the parameters compressive strength $\left(f_{c k}\right.$ estimated $)$ and modulus of elasticity $\left(\mathrm{E}_{28}\right)$.

\subsection{SAP2000}

The first numerical analysis was done using SAP2000 software with finite elements. The SAP2000 is a structural engineering software for linear and nonlinear static and dynamic analyses of several types of structures, simulating their behavior when submitted to a wide range of demands [8].

The software has a library of finite elements. Among the existing options, the elements that were used in the numerical models proposed in this study are described below.

\subsubsection{The Shell Element}

The Shell element is an area element used to model shells, membranes and plates in structures in two and three dimensions. The SAP2000 software defines two types of Shell element. They are denominated as Homogeneous Shell, used for homogenous materials, and as Layered Shell, used when the element is formed by heterogeneous materials or by more than one material. However, the software only allows nonlinear analyses when the element is a Layered Shell. Each element has its local coordinate system for the definition of material properties, loads and output of results. Tensions, internal forces and moments are determined by the Gauss quadrature method and extrapolated to the nodes. 


\section{Figure 7 - (a) Unevenly distribution of the load and (b) Slab totally loaded}

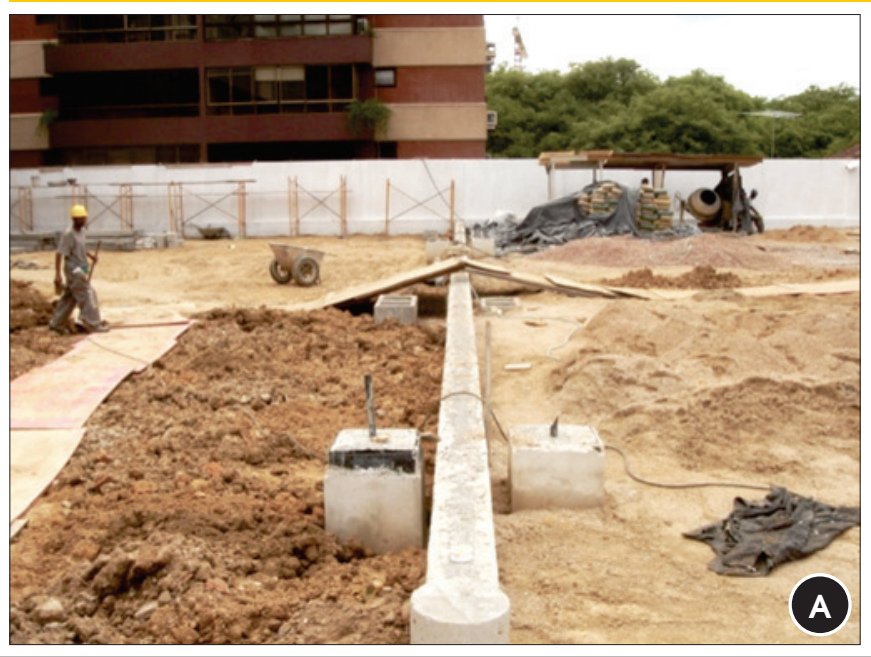

\subsubsection{The Frame Element}

The Frame Element is a tridimensional element with six degrees of freedom per node: three degrees of freedom for translation and three degrees of freedom for rotation. It is used for two or three dimensional modeling of frames, trusses and grids.

The formulation of the Frame element includes the determination of biaxial bending, torsion, axial and shear stress, through the integration of the tensions along the section. Those stresses

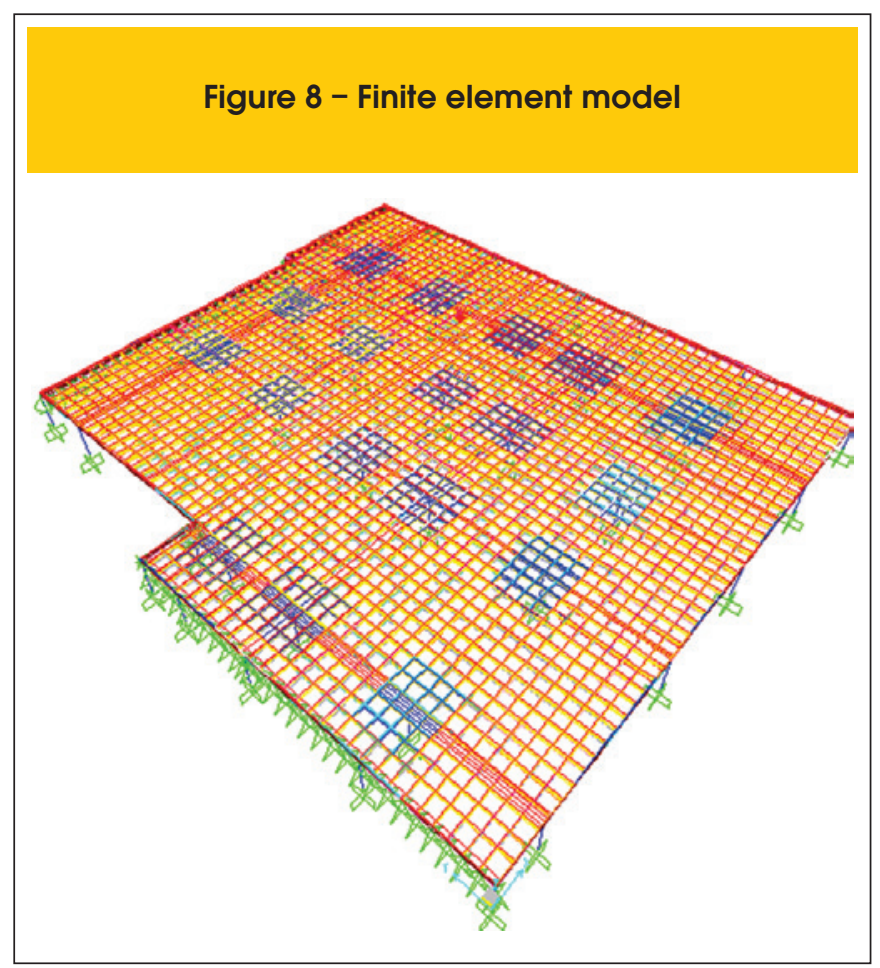

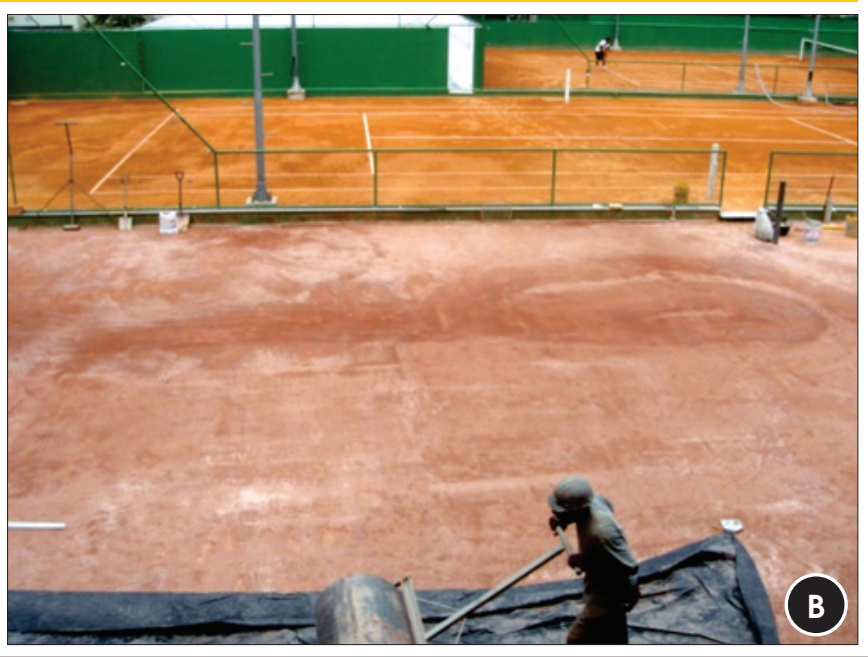

are determined at the ends of each element and at points along the element chosen by the user.

In the FE model of the waffle slab under study, which is shown in Fig. 8, the top slab, the ribs, the edge beams and the solid slab regions were modeled using shell elements, totaling approximately 23,000 elements, and the columns were modeled with frame elements. A nonlinear analysis of the structure was carried out, applying three types of loads in the following sequence: self-weight, a masonry load applied directly on the edge beams and the additional dead load. The numerical results corresponding to the experimental load were considered as being the difference between the values obtained from the numerical analysis at the first and the last stages of the additional dead load application (Fig. 9).

Figure 9 - Vertical displacements of instrumentation point PC concerning the loads applied on SAP2000

PC

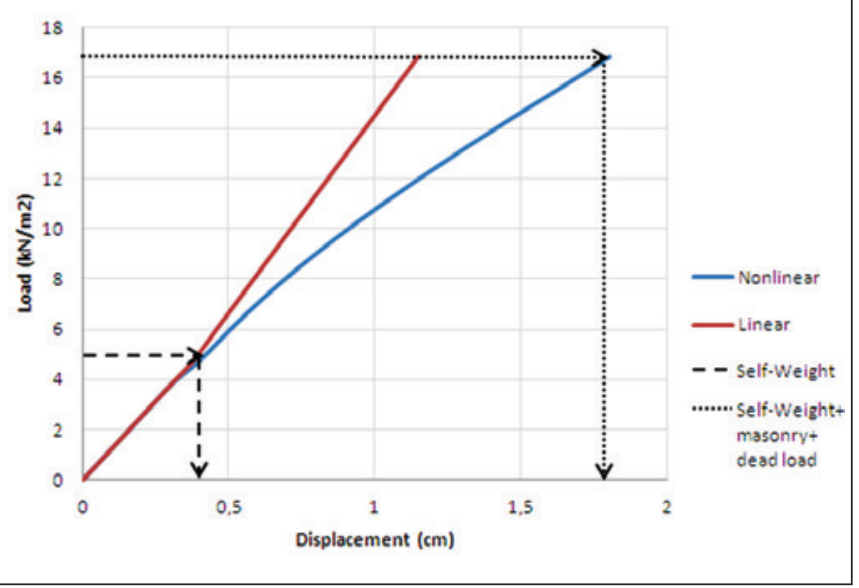




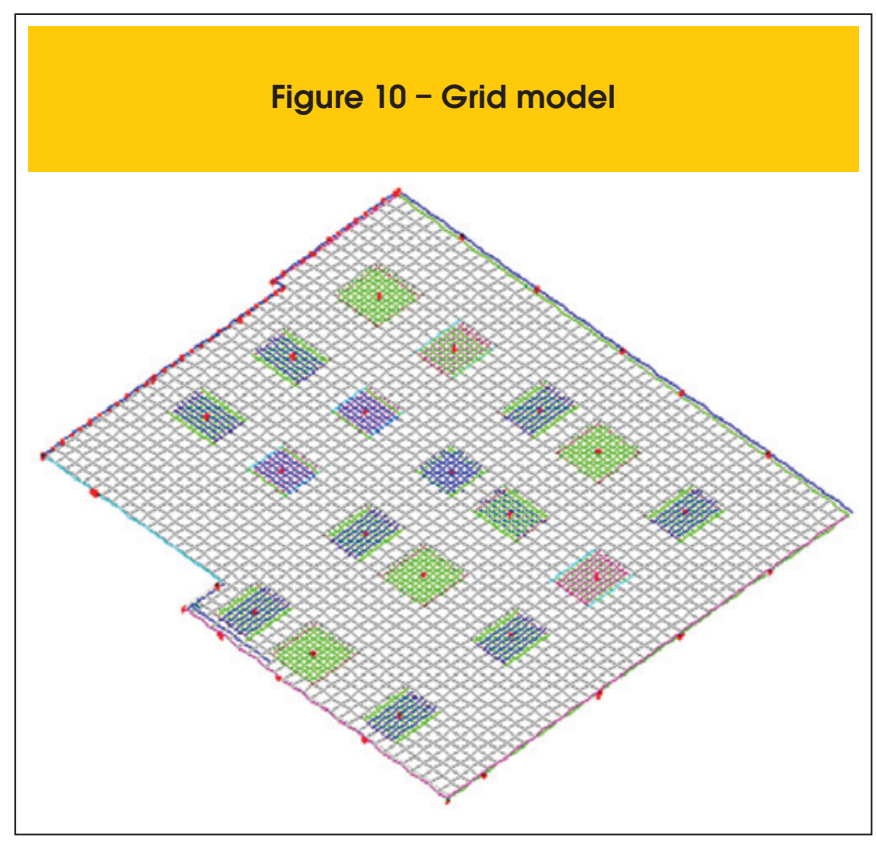

\subsection{TQS software}

$T Q S$ is a software developed by TQS Informática Ltda. for reinforced concrete structural design using the matrix analysis method for grids. This system, formed by a set of modules, creates a da- tabase on the entire construction, grouping geometries and loads, managing the structural analysis, the transference and calculation of stresses and the detailing of all the elements that constitute the structure [9].

In the case of waffle slabs, the TQS software allows both linear and non-linear grid analysis. In linear analysis, the reinforcement is not considered in the determination of the cross sections stiffness. Nonlinear analysis calculates the vertical displacements considering the reinforcement used and the physical non-linearity of concrete due to cracking, based on the recommendations of the Brazilian Concrete Code (ABNT, 2004[10]).

This software allows the structural designer to enter user defined values when determining stresses and detailing the reinforcement. In the specific case of waffle slabs, the most relevant choices are related to the structure's flexibility. The user may change the torsional and/or flexural inertia of the bars, as well as adjust the stiffness of the connections between beams and columns.

In this investigation, however, no reduction on torsional or flexural stiffness was used for the ribs or edge-beams. Additionally, the connections between ribs and beams and/or beams and columns were fully considered. This decision was made based on a parametric analysis, performed in a rectangular waffle slab, where the stiffness of the elements were varied and the results were compared to the ones obtained using the finite element program[7].

Given the necessary input data, the software automatically generates a numerical model of the slab, such as the one shown in Fig. 10. A nonlinear analysis of the structure was also carried out. However, in the case of nonlinear analysis, this computational pro-

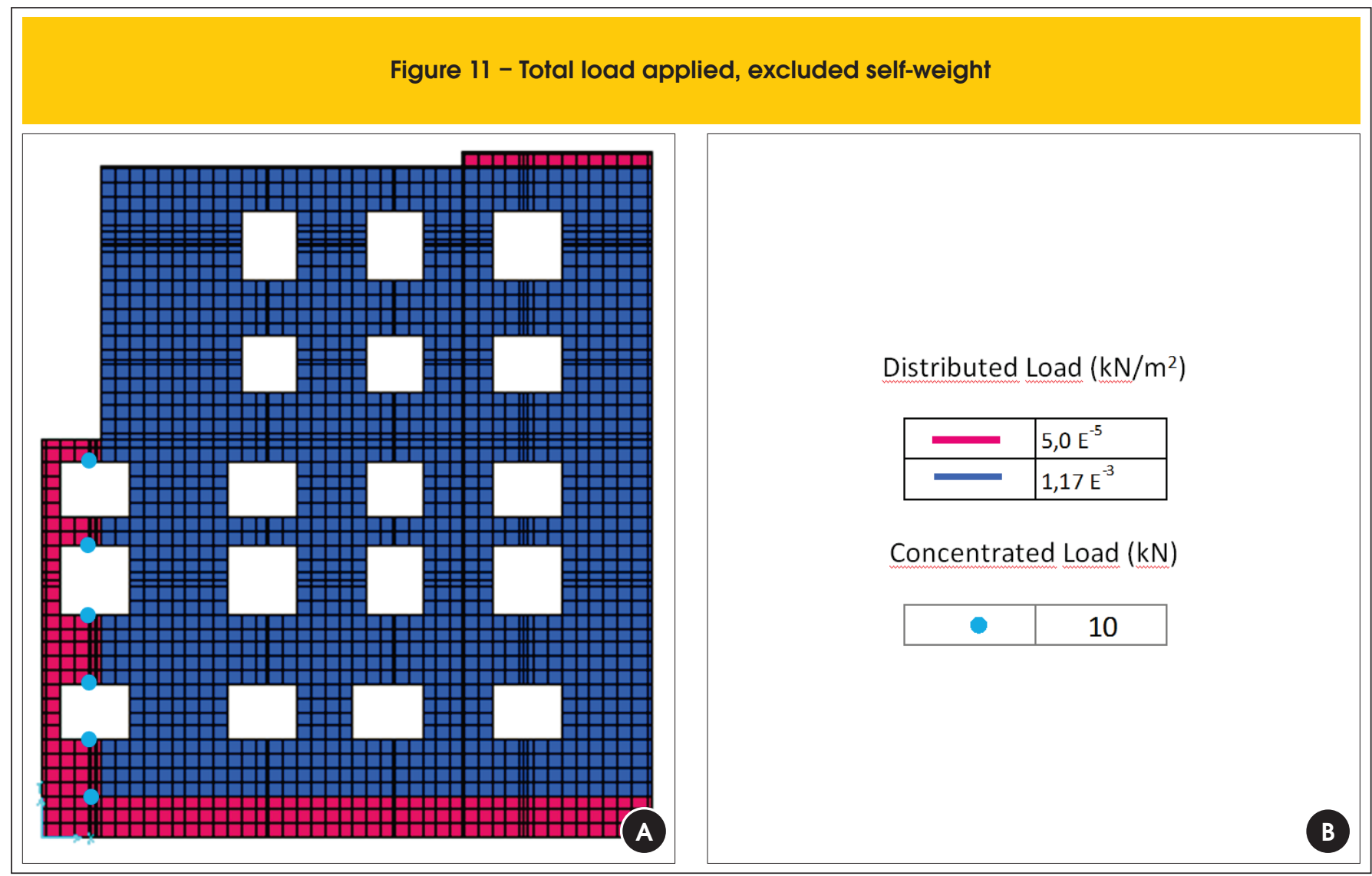


Figure 12 - TQS, SAP and experimental: deflections along line a shown in Fig. 6

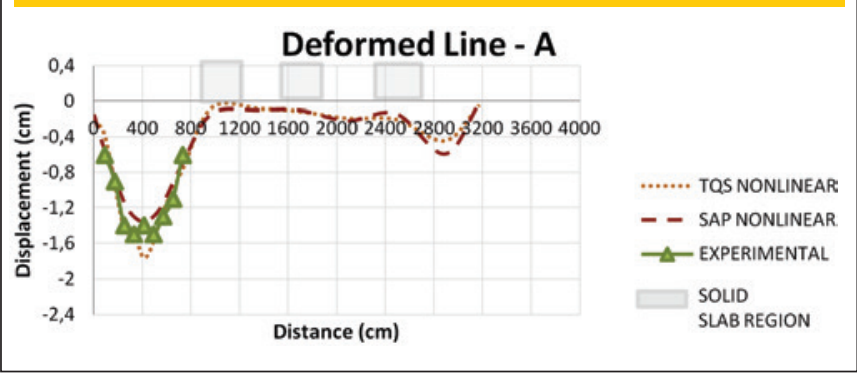

gram considers only the sum of all loads applied on the structure, including its self-weight. This load can, however, be divided into a number of stages to be defined by the user. Hence, in this study, the results originated only from the consideration of the additional dead load were obtained through the difference between two different analyses: one applying the sum of self-weight load, additional dead load and masonry applied straight on beams and the other applying only the self-weight and the masonry load on the beams.

\section{Analysis of the results}

This study presents the results obtained in the numerical analyses and those measured experimentally regarding the additional dead load applied as indicated in Fig. 11. Slab deflections and distribution of bending moments are compared using numerical and experimental results obtained along slab lines indicated as Line A and Line B as shown in Fig. 6.

\subsection{Vertical displacements}

Fig. 12 and 13 present deflection along slab lines $A$ and $B$ obtained with the nonlinear analyses of the structure as well as the values obtained experimentally.

A similar behavior is verified between numerical results of the two
Figure 13 - TQS, SAP and experimental: deflections along line B shown in Fig. 6

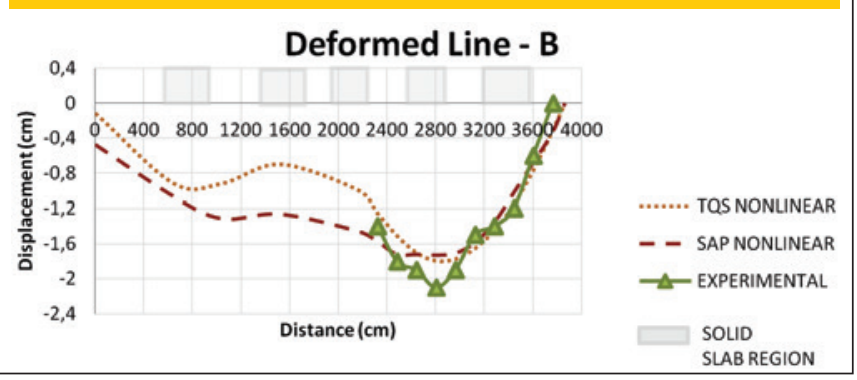

models and the experimentally measured data, showing that both numerical design strategies are fairly able to represent actual waffle slab deformed behavior.

\subsection{Bending moments}

In order to compare the numerical results with the ones obtained experimentally, the measured strains had to be transformed into bending moment estimates, considering the equilibrium of internal forces in the instrumented cross-sections [11].

Three values of bending moments were determined for each section, as shown in Fig. 14:

- Experimental uncracked section with calculated $\varepsilon_{\mathrm{s}}$ : Bending moment is calculated considering the uncracked cross-section, with the reinforcement strain inferred from a strain gradient defined from the experimental strain values measured;

- Experimental uncracked section with measured $\varepsilon_{\mathrm{s}}$ : Bending moment is calculated considering the uncracked cross-section, but takes into account the measured reinforcement strain. This estimate of the bending moment cracking onset concerns concrete contribution between cracks (tension stiffening effect);

- Experimental cracked section: Bending moment is calculated considering a cracked section with measured reinforcement strain.

Figure 14 - Strains used to determine experimental bending moments for (a) Uncracked section with $\varepsilon s$ deduced, (b) Uncracked section with $\varepsilon s$ measured and (c) Cracked section

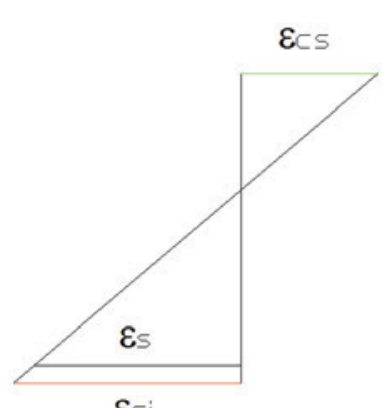

$\varepsilon \subset \mathrm{i}$

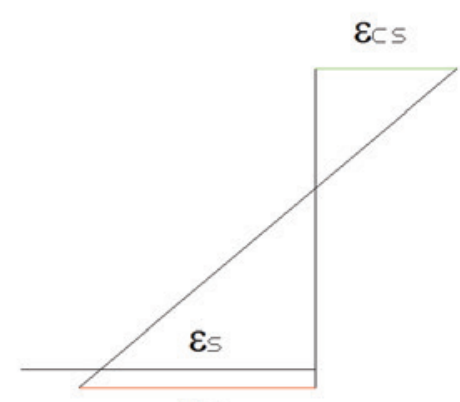

$\varepsilon \subset i$

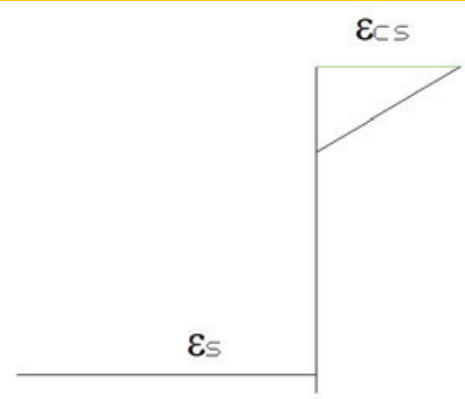

B 
Fig. 15 shows the distribution of bending moments obtained using both numerical models, compared to the estimates of bending moments derived from the experimental data obtained at location E1. Both numerical models present a similar shape, indicating maximum positive bending in the loading area and maximum negative moment in the solid slab region.

At location E1, the bending moment obtained experimentally using uncracked section with measured $\varepsilon$ s close to the values predicted by the numerical models, indicating a possible beginning of cracking around this section.

Both models indicate a negative moment between the ribs and the edge beams. The value indicated by the model in FE is, higher. This difference is probably due to the fact that this model considers the top slab as a continuous plate, generating greater clamping effect on the edge beam, when compared with the grid model.

Moreover, the FE model presents peaks of negative moments that are much more pronounced in the solid slab regions. This divergence may be associated to the different modeling of the solid slab regions in the softwares. At these locations, unfortunately no experimental data was collected, which could allow for a better assessment of the most adequate modeling for those connections and the influence of the solid slabs.

\section{Conclusions}

This study presented a comparative analysis between numerical and experimental results obtained for a reinforced concrete waffle slab designed to serve as a floor for tennis courts. The results indicate that, with the two numerical methods used, grid matrix analysis and finite elements, there are still issues that require further studies. The results also show the importance of undertaking experimental studies with the aim of verifying and adjusting the numerical models, particularly when new elements are adopted.

The main conclusions are:

1. The results of the numerical analysis of the waffle slab system, obtained through the grid analogy, represented here by the $T Q S$ software, show that modeling by this method is very effective, as long as the actual values for the moment of inertia are used with no reduction in the ribs, slab and beams, and rigid connections between the structural elements.

2. The finite element model, conceived in the SAP2000 software, proved to be equally adequate. However, when compared with the simplicity of an analogy to grids, the FE model proves to be very

\section{Figure 15 - Moments: SAP, TQS and experimental: bending moment along line A shown in Fig. 6}

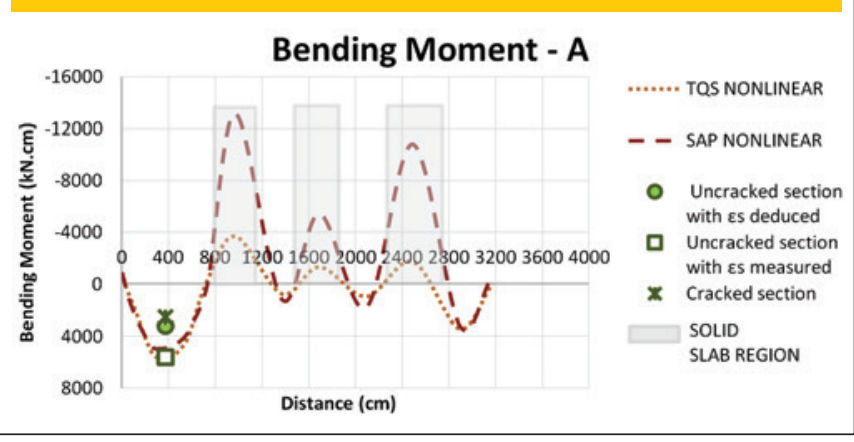

laborious, and difficult to use in the daily routine of design firms.

3. The grid analogy results in negative moments both in the slabedge beam connection and in the solid slab regions lower than those indicated by the finite element model. This difference in results may be related to the different modeling adopted by each computer program. Therefore, it is important the collection of experimental data that help define which of the models best represent this particular aspect of the behavior of a waffle slab.

\section{Aknowledgements}

The authors would like to thank CNPq (the Brazilian Research Council) and the companies Projetak - Tavares Eng. Associados S/C Ltda and Construtora Tedesco for the support they have given to this project.

\section{References}

[01] DIAS, R. H. Análise Numérica de Pavimentos de Edifícios em Lajes Nervuradas. Dissertação (Mestrado em Engenharia) - Escola de Engenharia de São Carlos, Universidade de São Paulo (USP), São Carlos, 2003.

[02] AJDUKIEWICZ, A.; STAROLSKI, W. Reinforcedconcrete slab-column stuctures. New York: Elsevier Science Publishers, 1986.

[03] SELISTRE, S. L.C. Análise Teórico-Experimental de uma Laje Nervurada de Microconcreto Submetida a um Carregamento Uniformemente Distribuído. Dissertação (Mestrado em Engenharia) - Curso de Pós-Graduação em Engenharia Civil, Universidade Federal do Rio Grande do Sul, Porto Alegre, 2000.

[04] ABDUL-WAHAB, H. M. S.; KHALIL, M. H. Rigidity and Strength of Orthotropic Reinforced Concrete Waffle Slabs. Journal of Structural Engineering, v. 126, n. 2, Feb., p. 219-227, 2000.

[05] SOARES, Y.V. Análise Experimental de Lajes Cogumelo Nervuradas de Concreto Armado com Pilares Metálicos. Dissertação (Mestrado em Engenharia) - Curso de Pós-Graduação em Engenharia Civil, UFSC, Florianópolis, 2003.

[06] SCHWETZ, P. F. Análise teórico-experimental de uma laje nervurada modelo reduzido sujeita a um carregamento linear. Dissertação (Mestrado em Engenharia) - Curso de Pós-Graduação em Engenharia Civil, UFRGS, Porto Alegre, 2005.

[07] SCHWETZ, P.F. Análise Numérico-Experimental de Lajes Nervuradas Sujeitas a Cargas Estáticas de Serviço. Tese (Doutorado em Engenharia) - Escola de Engenharia, Universidade Federal do Rio Grande do Sul, Porto Alegre, 2011.

[08] COMPUTERS AND STRUCTURES, INC. CSI Analysis Reference Manual. Berkeley: University Avenue, 2010.

[09] TQS Informática Ltda. (a). Sistemas Computacionais - Engenharia Estrutural: CAD/Formas. São Paulo, s.d. várias paginações.

[10] ASSOCIAÇÃO BRASILEIRA DE NORMAS TÉCNICAS. NBR 6118:2003 : projeto e execução de obras de concreto armado. Rio de Janeiro, 2004.

[11] PARK R.; PAULAY T. Reinforced Concrete Structures. University of Canterbury, Christchurch, New Zeland, 1975. 